\title{
The role of the hotel industry in the response to emerging epidemics: a case study of SARS in 2003 and H1N1 swine flu in 2009 in Hong Kong
}

\author{
Kevin K. C. Hung ${ }^{1,2}$, Carman K. M. Mark², May P. S. Yeung ${ }^{2}$, Emily Y. Y. Chan ${ }^{1,2}$ and Colin A. Graham ${ }^{1,2^{*}}$ (D)
}

\begin{abstract}
Background: The global travel and tourism industry has been rapidly expanding in the past decades. The traditional focus on border screening, and by airline and cruise industries may be inadequate due to the incubation period of an infectious disease. This case study highlights the potential role of the hotel industry in epidemic preparedness and response.

Methods: This case study focuses on the epidemic outbreaks of SARS in 2003 and H1N1 swine flu in 2009 in Hong Kong, and the subsequent guidelines published by the health authority in relation to the hotel industry in Hong Kong which provide the backbone for discussion.

Results: The Metropole Hotel hastened the international spread of the 2003 SARS outbreak by the index case infecting visitors from Singapore, Vietnam, Canada as well as local people via close contact with the index case and the environmental contamination. The one-week quarantine of more than 300 guests and staff at the Metropark Hotel during the 2009 H1N1 swine flu exposed gaps in the partnership with the hotel industry. The subsequent guidelines for the hotel industry from the Centre of Health Protection focused largely on the maintenance of hygiene within the hotel premises.

Conclusion: Positive collaborations may bring about effective preparedness across the health and the tourism sectors for future epidemics. Regular hygiene surveillance at hotel facilities, and developing coordination mechanism for impending epidemics on the use of screening, swift reporting and isolation of infected persons may help mitigate the impact of future events. Preparedness and contingency plans for infectious disease control for the hotel industry requires continuous engagement and dialogue.
\end{abstract}

Keywords: Epidemics, Hotel industry, Infection control, International travel, Private sector engagement, Quarantine, Tourism, Health-related emergency disaster risk management

\section{Background}

The global travel and tourism industry has expanded rapidly in recent years. The global number of international tourist arrivals increased from approximately 541 million in 1995 to 1161 million in 2014 [1]. The ever greater numbers present enormous challenges to the

\footnotetext{
* Correspondence: cagraham@cuhk.edu.hk

${ }^{1}$ Accident and Emergency Medicine Academic Unit, The Chinese University

of Hong Kong, Trauma \& Emergency Centre, Prince of Wales Hospital, Shatin, New Territories, Hong Kong

${ }^{2} \mathrm{JC}$ School of Public Health and Primary Care, The Chinese University of Hong Kong, Prince of Wales Hospital, Shatin, New Territories, Hong Kong
}

entire global community for epidemic preparedness and control. The increasing complexity of frequent international travel opens an ideal route for local outbreaks of infectious disease to becoming global pandemics.

The health and wellbeing of travellers warrants appropriate consultation and treatment in its own right, but in the case of infectious diseases of major public health concern, it is important to address the public health aspects of their illness as patients are also disease carriers promoting the spread of infectious disease on a potentially global scale. The International Health

(c) The Author(s). 2019 Open Access This article is distributed under the terms of the Creative Commons Attribution 4.0 International License (http://creativecommons.org/licenses/by/4.0/), which permits unrestricted use, distribution, and reproduction in any medium, provided you give appropriate credit to the original author(s) and the source, provide a link to the Creative Commons license, and indicate if changes were made. The Creative Commons Public Domain Dedication waiver (http://creativecommons.org/publicdomain/zero/1.0/) applies to the data made available in this article, unless otherwise stated. 
Regulations (IHR) (2005) form one of the few legally binding instruments of the World Health Organisation (WHO). The purpose and the scope of IHR (2005) are "to prevent, protect against, control and provide a public health response to the international spread of disease in ways that are commensurate with and restricted to public health risks, and which avoid unnecessary interference with international traffic and trade" [2].

Most of the existing research in travel medicine and the current guidelines for international health authorities emphasise the role of the air-travel industry in tracking and thus containing the potential international spread of infectious disease. For instance, the WHO guideline on International Travel and Health highlights the role of airlines as well as shipping companies, together with that of tour operators and travel agents in limiting the spread of infectious disease across borders [3]. Similarly, the Centres for Disease Control and Prevention (CDC) guidelines focus on the airline and cruise industries [4]. The role of the other important sector in tourism, namely the hotel industry, have been less clearly defined and discussed.

This case study will use the example of the Metropole Hotel in Hong Kong in the international spread of Severe Acute Respiratory Syndrome (SARS) in 2003, and the effect of the government mandated quarantine of the Metropark Hotel during the swine flu 2009 in Hong Kong.

SARS was caused by the SARS-associated coronavirus, with the primary mode of transmission being direct mucous membrane contact with infectious respiratory droplets [5, 6]. It had a basic reproduction number of approximately 3 , and the spread was mainly to those with close contact in health care and household settings. The first cases were identified in Guangdong province of China in November 2002, and a number of natural reservoirs have been found including civet cats and bats. Incubation period ranged from 3 to 10 days [7]. The overall case fatality ratio was $9.6 \%$ worldwide, with deaths resulting from pneumonia and subsequent respiratory failure. The travel industry contributed to the speed of the spread of this unknown disease at that time, particularly within the Metropole Hotel as it was the first site for global dissemination of the virus [8]. SARS subsequently caused 774 deaths in 26 countries, with the disease spreading to cover five continents [7]. This case vividly illustrates how a local outbreak can rapidly evolve into a global pandemic.

The H1N1 swine flu pandemic in 2009 was caused by the $\mathrm{A}(\mathrm{H} 1 \mathrm{~N} 1)$ pdm09 influenza virus [9]. This strain containing genes from pig, bird and human influenza viruses has never been reported before 2009, and the outbreak was first identified in March 2009 in Mexico and the United States. It was estimated that between 151,700 and 575,400 deaths resulted globally, with $80 \%$ in people younger than 65 years old from respiratory and cardiovascular influenza related complications. The $2009 \mathrm{H} 1 \mathrm{~N} 1$ virus infection mortality was estimated to be $0.001-0.011 \%$ of the world's population, much lower than the previous $0.03 \%$ during the 1968 pandemic and the $1-3 \%$ of the 1918 pandemic [10]. The first imported case in Hong Kong was tested positive for swine influenza on the 1 May 2009 [11]. This has led to the subsequent quarantine of all guests and staff at the Metropark Hotel for 1 week.

Hotels can be a critical component in the evolution of a local outbreak into a global pandemic, and an initial contact point of the import of an impending global pandemic. The aim of this paper is to highlight the role of hotel in the spread of epidemic, and discuss control measures that can be implemented.

\section{Methods}

This case study focuses on the epidemic outbreaks of SARS in 2003 and H1N1 swine flu in 2009 in Hong Kong. Secondary information was extracted from the literature search and the grey literature looking for published official reports, statements, policy papers, field reports and guidelines for further discussion on the role of the hotel industry on the epidemics. Public health principles of disaster response were used to provide the backbone for discussion.

MEDLINE was used to identify research articles published between 1 January 2000 and 31 December 2017 in the English language, to answer these specific questions: 1 . what factors in the hotel setting contributed to international spread of SARS; 2 . the decision making and implementation of hotel quarantine during swine flu, and the impact of the hotel quarantine.

Any study design regarding aspects on timelines of sequence of events, environmental sampling and contamination, evaluation of hotel related interventions, modelling of interventions were included. Studies not meeting the above inclusion criteria or answering the research questions was excluded.

The search for grey literature involved the searching and browsing the websites of relevant organisations including the World Health Organisation, US CDC, EU European Centre for Disease Prevention and Control, Hong Kong Centre for Health Protection and Department of Health, Food and Health Bureau of Hong Kong SAR government, SARS expert committee, Hong Kong Government information page.

MEDLINE (Ovid SP) search was performed using these terms: (Disease outbreaks [mesh] OR Epidemics [mesh] OR Pandemics [mesh] OR Severe Acute Respiratory Syndrome [mesh] OR Influenza A Virus, H1N1 Subtype [mesh]) AND Hotel [keyword]. 


\section{Results}

The search identified 34 records from MEDLINE of which five were relevant (references [6, 12-15]), and an additional 13 records were identified through other sources and the grey literature.

\section{SARS 2003}

A medical professor from Guangzhou in China arrived in Hong Kong on 21 February 2003 and checked into a room on the ninth floor of the Metropole Hotel in Kowloon [16]. During his stay, he infected at least seven other guests and visitors staying on the ninth floor of the hotel including three visitors from Singapore, one visitor from Vietnam, two visitors from Canada and a local individual [17].

On 8 March 2003, the Singapore Ministry of Health reported to the Hong Kong Department of Health that three patients who presented with pneumonia were admitted to hospital after returning to Singapore from Hong Kong. They had all stayed in the Metropole Hotel. During the conversation, laboratory investigations were pending and there was not sufficient evidence to suggest that their illnesses had been related to the Metropole Hotel [16].

On 12 March 2003, the WHO issued a global alert about unusual cases of an acute respiratory syndrome. On 14 March 2003, the index case for the significant outbreak at the Prince of Wales Hospital was identified. It was not until 19 March 2003, after multiple enquiries, the patient revealed that he had visited the Metropole Hotel around that period as a visitor but not a guest [16]. On the same day, the Hong Kong Department of Health reported the chain of transmission of the outbreak at the Metropole Hotel [16].

The Metropole Hotel exemplified the potential international spread of infectious diseases. The index cases in the Hong Kong, Toronto, Singapore and Hanoi outbreaks were all associated with the hotel. SARS patients in Ireland and United States had also visited the Metropole Hotel around the same time when there were other sick guests present in the hotel $[12-14,18]$. Subsequently there were hospital outbreaks when these index cases returned and were treated at their home countries. Table 1 showed the timeline of the 2003 SARS action of the Department of Health.

Little was known about the new disease SARS when the outbreak began at hotel and hospitals in February and early March. The WHO did not issue its first emergency travel advisory naming the illness as SARS until 15 March 2003 [16]. There was local media coverage of an outbreak of atypical pneumonia in Guangzhou on 10 February 2003, and the health authority in Hong Kong had made contact with the Guangzhou and Guangdong authorities. However, accurate information about the atypical pneumonia outbreak in Guangdong Province was not available to Hong Kong or the international community at the time. Case investigation and contact tracing conducted by the Department of Health on 24 February 2003 on the index case revealed that the Guangzhou professor and his wife had stayed at the Metropole Hotel. However, no contact tracing was conducted in the hotel at that stage since the Department of Health had not received any other reports of severe community-acquired pneumonia related to the hotel [16]. There were no environmental factors or triggers identified that warranted further action. However, environmental sampling on the carpet outside the room in which the index case resided, and elevator area showed a hot zone which tested positive for the SARS virus by polymerase chain reaction (PCR) 3 months after the index case stayed at the hotel [19]. Another study investigating German guests staying at the hotel also suggested the possibility of environmental contamination as a source of infection [15]. It is not known how long the infectious virus persists in the surroundings of a SARS patient. The established practice was for contact tracing

Table 1 Hong Kong Health Authority's action to hotel industry during SARS 2003

\begin{tabular}{|c|c|}
\hline Date & Action by the Health Authority \\
\hline 21 February 2003 & $\begin{array}{l}\text { A medical professor from Guangzhou in China arrived in Hong Kong and checked into a room on the nint } \\
\text { floor of the Metropole Hotel in Kowloon. He was later found to be the source of SARS outbreak in Hotel M } \\
\text { and beyond. }\end{array}$ \\
\hline 14 March 2003 & The Secretary for Health, Welfare and Food sets up and chairs the 1st meeting of Task Force on SARS. \\
\hline 19 March 2003 & $\begin{array}{l}\text { Department of Health }(\mathrm{DH}) \text { announced the chain of transmission of at least } 7 \text { SARS cases were related to } \\
\text { the Hotel } \mathrm{M} \text {, the index case of the epidemic in Hong Kong. }\end{array}$ \\
\hline 19 and 20 March 2003 & $\begin{array}{l}\text { DH's Kowloon Regional Office conducted site investigation at Hotel M. DH ensured hotel management } \\
\text { conducted proper cleansing and disinfection. }\end{array}$ \\
\hline 22 March 2003 & $\begin{array}{l}\text { DH inspected hotel environment inspected and found satisfactory and informed hotel management that } \\
\text { they could resume business on } 9 / F \text {. }\end{array}$ \\
\hline 28 May and 6 June 2003 & $\begin{array}{l}\text { DH met with tourism and hotel industries, Tourism Commission and Tourism Board on health awareness } \\
\text { programme for visitors. }\end{array}$ \\
\hline
\end{tabular}


to be conducted on close contacts (friends or family), but not on the basis of a shared location [16].

A number of researchers estimated the basic reproduction number of SARS by fitting models to the initial growth of the epidemics in a number of countries [19]. Modelling of SARS epidemiology in Hong Kong and China showed rapid public health measures such as contact tracing for confirmed and suspected cases, and quarantining, monitoring, and restricting the travel of contacts had an effective reduction in reproduction number [20-23].

\section{Swine flu 2009}

A 25-year-old male from Mexico arrived in Hong Kong on 30 April 2009, and stayed at the Metropark Hotel. He attended hospital on the same evening where he was admitted to an isolation ward. He subsequently developed a fever and was confirmed to have swine flu on 1 May 2009 [11].

The Hong Kong Special Administrative Region (HKSAR) government raised the response level to 'Emergency' on the same day under the Emergency Preparedness Plan for Influenza Pandemic. An 'Emergency Response Level Steering Committee on Human Swine Influenza (Flu A H1N1) Pandemic' was also established on the 1st May to formulate the overall disease control strategy [11].

Under the Prevention and Control of Disease Ordinance, the Director of Health ordered that all guests and staff at the Metropark Hotel should be quarantined on the evening of 1 May 2009 [11]. The quarantine was led by the Department of Health in collaboration with other government departments. Quarantined persons were provided with oseltamivir (Tamiflu) and other medical treatment. The Social Welfare Department provided daily necessities and emotional support to the quarantined. A help desk was set up at the hotel involving the Department of Health, the Home Affairs Department, the Social Welfare Department, the Immigration Department, the Civil Aid Service, the Auxiliary Medical Service and the Police.

The quarantine ended 1 week later, which covered the incubation period of influenza of 1 to 7 days. For those persons who had completed the quarantine period without showing symptoms of being infected, they were issued with Certificates of Conclusion of Quarantine.

At the same time, the Centre for Health Protection (CHP), other government departments and relevant agencies conducted contact tracing starting on the 1st May 2019. Close and selected social contacts were prescribed chemoprophylaxis and put under medical surveillance. The hotel and nearby streets, as well as other public places, were cleansed and disinfected. Hygiene guidelines had been issued to all licensed hotels/ guesthouses and rented rooms to encourage enhanced cleansing and improvement of hygiene. All industrial associations had been informed of the situation and reminded the need to take precautionary measures. The Occupational Safety and Health Council had organised public seminars to raise public awareness of preparedness for influenza in the workplace [11]. Table 2 showed the timeline of the 2009 swine flu action of the Department of Health.

\section{Characteristics of hotels involved}

Both the Metropole Hotel at Kowloon (now renamed Metropark Hotel Kowloon) and the Metropark Hotel at Wan Chai (now renamed Kew Green Hotel) were four stars hotels situated at busy part of the city. Both hotels were managed by the same management group - the China Travel Service (Holdings) Hong Kong Limited. The two hotels were no different in terms of access to public health facilities and general standard of care. The difference in the timing of public health actions by the health authority was likely contributed by experience of SARS preceding swine flu.

\section{Government initiatives on epidemic preparedness with the hotel industry after SARS and swine flu}

After the SARS outbreak in Hong Kong the health authority established the Guidelines for Hotels in Preventing Severe Acute Respiratory Syndrome (SARS) [24]

Table 2 Hong Kong Health Authority's action to hotel industry during Swine flu 2009

\begin{tabular}{ll}
\hline Date & \multicolumn{1}{c}{ Action by the Health Authority } \\
\hline 30 April 2009 & A 25-year-old male from Mexico (index patient) arrived in Hong Kong and stayed at the Metropark Hotel. \\
1 to 7 May 2009 & $\begin{array}{l}\text { The Director of Health ordered that the Metropark Hotel should be isolated. All guests and staff were } \\
\text { quarantined. Quarantined persons were provided with oseltamivir (Tamiflu) and other medical treatment. } \\
\text { Department of Health conducted contact tracing in the disease containment phase }\end{array}$ \\
1 May 2009 & $\begin{array}{l}\text { Cleansing and disinfection of the hotel lobby and common areas as well as bathrooms in individual guest } \\
\text { rooms have been arranged by Food and Environmental Hygiene Department (FEHD). }\end{array}$ \\
Early May 2009 & $\begin{array}{l}\text { The Metropark Hotel as well as } 8 \text { other hotels/hostels in which passengers of flight MU505 (flight of the index } \\
\text { patient) had stayed have been disinfected. } \\
\text { Early May } 2009\end{array}$ \\
& $\begin{array}{l}\text { Hygiene guidelines have been issued to all owners' corporations, owners' committee, mutual assistance } \\
\text { committees and the Hong Kong Association of Property Management Companies, licensed hotels/guesthouses } \\
\text { and bed space apartments to encourage enhanced cleansing and improvement of hygiene. }\end{array}$
\end{tabular}


and Guidelines on Infection Control \& Prevention in the Hotel Industry [25]. The guidelines provided practical information for hotel staff members on how measures to prevent communicable diseases should be done. It offered comprehensive information on ways to implement infection control measures, in particular the maintenance of good hygiene on hotel premises [25].

The CHP organised Infection Control Seminars for the Hotel Industry on a regular basis. For instance, in response to the Ebola virus outbreak in West Africa in 2014-2016, the CHP provided advice for the local hotel industry on receiving guests with a travel history or residence in an Ebola virus disease affected area. The guideline stressed the importance of enquiring about the travel history of guests and outlined procedures on handling these guests who may feel unwell. The guideline reiterated the need to keep a record of staff and residents who had stayed in the hotel, with their personal and contact details, for possible future public health actions and contact tracing [26].

Ideally, hotels should be setting their own standards of hygiene measures and providing training to staff before an outbreak occurs. Further roles and responsibilities included contingency arrangement, plan of acquisition of protective equipment, disease reporting and surveillance mechanism during outbreak period [27].

From our online and database internet search, however, there is little mention of collaboration between the government and the hotel industry. No documentation was found on setting up of task forces or committees, or of invitation to hotel representatives to the working group advising on infection control guidelines in Hong Kong.

\section{Discussion}

SARS served as the classic example of how tourism and international travel can present challenges to the global health system. The spread of the illness within a single hotel and the subsequent international air travel of the victims contributed to and accelerated the speed of the spread of SARS across the globe.

The experience from SARS in Hong Kong had a profound impact on the public health reform especially on the infectious disease surveillance and epidemic response [16]. These included strengthening the surveillance and the isolation and treatment of individuals with the disease according to case definitions, the establishment of communication channels between hotel and the government system, and the development of guidelines and response plans that allows the implementation of stringent infection control measures when necessary. The establishment of contingency plans and command structures including the 'Emergency Response Level Steering Committee on Influenza Pandemic' allowed a clear structural framework and key lines of responsibility
[28]. However, collaboration with the private sector and the hotel industry were found to be limited and focused around infection control measures.

According to subsequently published literature, application of appropriate measures had likely reduced the number of people who were infected, requiring medical care and died during the influenza pandemic [29]. It has been shown that case isolation or household quarantine could have a significant impact at reducing attack rates in the community, and chemoprophylaxis can greatly reduce disease transmission during the pandemic [30, 31]. However, the quarantine of guests at the Metropark Hotel in 2009 inevitably stirs up much discussion and controversy among the media and the public health community on the balance between the need to protect the public health and the need to safeguard civil liberties.

The decision of quarantine created enormous tension between the government, guests and the hotel management. The decision of the need for quarantine and the scale of the quarantine needs to be scientifically justified. The negative effects overall of such a policy on the tourism attractiveness of a destination cannot be neglected. The quarantine at the Metropark Hotel during swine flu also highlighted the extensive assistance needed for the quarantined persons, and the cooperation necessary in the possible future need for a hotel quarantine. Pre-established partnerships and coordination between the government and the hotel industry is key in epidemic preparedness and response.

\section{Effects of epidemics on the hotel industry}

Studies have shown that the psychological impacts of SARS and the government restrictions on travel, had a great impact on the travel industry far beyond the region of SARS hit areas [32]. For the hotel industry in Hong Kong, the number of hotel guests dropped dramatically to a level that was never experienced before [33]. In order for hotels to sustain their business, the Hong Kong hotel industry adopted an industry-wide recovery effort and empathized on mutual support [26]. Previous papers called for a better preparedness of the hotel industry for future crises and epidemics [32, 33].

\section{Collaborations with the hotel industry to mitigate the impact of epidemics}

Hotels are often the first point of contact for tourists arriving at a host country. Hotels could provide an additional line of defence beyond entry border screening, and they could offer another layer of protection against illnesses that border screening processes may have missed, for example in the situation where travel occurs during the incubation period of an infectious disease. In view of this, the capacity of hotels in the detection of 
potential illness and the launching of an initial response should be fully recognised and utilised.

The WHO pandemic influenza risk management recommended involving civil society and the private business sector in pandemic preparedness planning and national committees [34]. The case of hotel industry collaboration with the health sector in Hong Kong has the potential to provide a positive example of effective disaster risk reduction coordination.

\section{Conclusions}

The epidemic preparedness and infection control measures mounted against SARS and H1N1 swine flu demonstrated a role that needed to be filled by the hotel industry. During SARS, late recognition of the environmental contamination of hotel facilities and the failure of timely intervention on the hotel guests with close contact contributed to the spread of the disease internationally. While the appropriateness and best method of quarantine in future pandemic influenza warrants further research, the 2009 swine flu hotel quarantine exposed gaps in the partnership with hotel industry. Health authorities in Hong Kong had since provided guidelines mostly in the area of disinfection and hygiene, and focused on educating hotel workers on basic hygiene to prevent the spread of infectious diseases. The potential to establish traveller screening, timely reporting and isolation for the infected guests during epidemics could be explored. The capacity of the hotel industry in controlling infections should be recognised not only in Hong Kong but also in other parts of the world.

\section{Acknowledgements}

Not applicable.

Funding

No funding available for this study.

Availability of data and materials

Not applicable.

\begin{abstract}
Authors' contributions
Conceptualization, $\mathrm{KH}$ and $\mathrm{CM}$; Data curation, $\mathrm{CM}$ and MY; Formal analysis, $\mathrm{KH}$ and $\mathrm{CG}$; Supervision, EC and CG; Writing - original draft, $\mathrm{KH}$ and $\mathrm{CM}$; Writing - review \& editing, MY, EC and CG. All authors read and approved the final manuscript
\end{abstract}

Ethics approval and consent to participate

Not applicable.

\section{Consent for publication}

Not applicable.

\section{Competing interests}

The authors declare that they have no competing interests.

\section{Publisher's Note}

Springer Nature remains neutral with regard to jurisdictional claims in published maps and institutional affiliations.
Received: 9 July 2018 Accepted: 13 November 2018

Published online: 27 November 2018

\section{References}

1. The World Bank. International tourism, number of arrivals. Available from: http://data.worldbank.org/indicator/ST.INT.ARVL?view=map. Accessed 29 May 2018.

2. World Health Organization. International Health Regulations. 2005. Available at: http://www.who.int/ihr/publications/9789241580496/en/. Accessed 29 May 2018.

3. World Health Organization. International travel and health. Available at: http://who.int/ith/ITH_EN_2012_WEB_1.2.pdf?ua=1. Accessed 29 May 2018.

4. Centers for Disease Control and Prevention. Travel Industry Resources. Available at: https://wwwnc.cdc.gov/travel/page/travel-industry-informationcenter. Accessed 29 May 2018.

5. European Centre for Disease Prevention and Control. Facts about severe acute respiratory syndrome (SARS). Available at: https://ecdc.europa.eu/en/ severe-acute-respiratory-syndrome/facts. Accessed 1 Nov 2018.

6. Chan PK, Tang JW, Hui DS. SARS: clinical presentation, transmission, pathogenesis and treatment options. Clin Sci. 2006;110(2):193-204.

7. World Health Organisation. Summary of probable SARS cases with onset of illness from 1 November 2002 to 31 July 2003. Available at: http://www. who.int/csr/sars/country/table2004_04_21/en/. Accessed 29 May 2018.

8. Institute of Medicine (US) Forum on Microbial Threats; Knobler S, Mahmoud A, Lemon S, et al., editors. Learning from SARS: Preparing for the Next Disease Outbreak: Workshop Summary. Washington (DC): National Academies Press (US); 2004. Available from: https://www.ncbi.n/m.nih.gov/ books/NBK92462/. https://doi.org/10.17226/10915. Accessed 1 Nov 2018.

9. European Centre for Disease Prevention and Control. Factsheet on swine influenza in humans. Available at: https://ecdc.europa.eu/en/swineinfluenza/facts/swine-influenza-humans. Accessed 1 Nov 2018.

10. Dawood FS, luliano AD, Reed C, Meltzer MI, Shay DK, Cheng PY, Bandaranayake D, Breiman RF, Brooks WA, Buchy P, Feikin DR. Estimated global mortality associated with the first 12 months of 2009 pandemic influenza A H1N1 virus circulation: a modelling study. Lancet Infect Dis. 2012;12(9):687-95

11. Advisory Council on Food and Environmental Hygiene. Prevention and control of Human Swine Influenza infection in Hong Kong. ACFEH Paper 97. Food and Health Bureau. Available at: http://www.fhb.gov.hk/download/ committees/board/doc/2009/paper20090525_97.pdf. Accessed 29 May 2018

12. Skowronski DM, Astell C, Brunham RC, Low DE, Petric M, Roper RL, Talbot PJ, Tam T, Babiuk L. Severe acute respiratory syndrome (SARS): a year in review. Annu Rev Med. 2005;56:357-81.

13. Zhong NS, Wong GW. Epidemiology of severe acute respiratory syndrome (SARS): adults and children. Paediatr Respir Rev. 2004;5(4):270-4

14. Braden CR, Dowell SF, Jernigan DB, Hughes JM. Progress in global surveillance and response capacity 10 years after severe acute respiratory syndrome. Emerg Infect Dis. 2013;19(6):864.

15. Radun D, Niedrig M, Ammon A, Stark K. SARS: retrospective cohort study among German guests of the hotel 'M', Hong Kong. Euro Surveill. 2003; 8(12):228-30.

16. SARS Expert committee. SARS in Hong Kong: from Experience to Action Available at: http://www.sars-expertcom.gov.hk/english/reports/summary/ reports_sumrpt.html. Accessed 29 May 2018.

17. Lee SH. The SARS epidemic in Hong Kong: what lessons have we learned? J R Soc Med. 2003;96(8):374-8

18. Centers for Disease Control and Prevention. Update: outbreak of severe acute respiratory syndrome - worldwide, 2003. Morb Mortal Wkly Rep. 2003:52:241-8.

19. World Health Organization. Consensus document on the epidemiology of severe acute respiratory syndrome (SARS). Available at: http://www.who.int/ entity/csr/sars/en/WHOconsensus.pdf. Accessed 29 May 2018.

20. Donnelly CA, Ghani AC, Leung GM, Hedley AJ, Fraser C, Riley S, Abu-Raddad LJ, Ho LM, Thach TQ, Chau P, Chan KP. Epidemiological determinants of spread of causal agent of severe acute respiratory syndrome in Hong Kong. Lancet. 2003:361(9371):1761-6.

21. De Vlas SJ, Feng D, Cooper BS, Fang LQ, Cao WC, Richardus JH. The impact of public health control measures during the SARS epidemic in mainland China. Tropical Med Int Health. 2009;14:101-4. 
22. Anderson RM, Fraser C, Ghani AC, Donnelly CA, Riley S, Ferguson NM, Leung GM, Lam TH, Hedley AJ. Epidemiology, transmission dynamics and control of SARS: the 2002-2003 epidemic. Philos Trans R Lond B. 2004; 359(1447):1091-105.

23. Hsieh YH, King CC, Chen CW, Ho MS, Hsu SB, Wu YC. Impact of quarantine on the 2003 SARS outbreak: a retrospective modeling study. J Theor Biol. 2007;244(4):729-36.

24. Hong Kong Special Administrative Region (HKSAR) Government. Preventing Severe Acute Respiratory Syndrome (SARS) Guidelines for Hotels. Available at: http://www.info.gov.hk/info/sars/en/GuidelinesForHotels.htm. Accessed 29 May 2018.

25. Centre for Health Protection. Guidelines on infection control and prevention in hotel industry. Centre for Health Protection. Available at: http://www.chp. gov.hk/files/pdf/105_guideline_on_infection_controland_prevention_in_ hotel_industry.pdf. Accessed 29 May 2018.

26. Centre for Health Protection. Health advice for hotel industry on serving guests with history of travel to or resided in the Ebola Virus Disease (EVD) affected areas. Available at: http://www.chp.gov.hk/files/pdf/health_advice_ for_hotel_industry_evd_eng.pdf. Accessed 29 May 2018.

27. Chien GC, Law R. The impact of the severe acute respiratory syndrome on hotels: a case study of Hong Kong. Int J Hosp Manag. 2003;22(3):327-32.

28. Preparedness Plan for Influenza Pandemic The Government of the Hong Kong Special Administrative Region. 2014. Available at: https://www.chp. gov.hk/files/pdf/erib_preparedness_plan_for_influenza_pandemic_2014_ eng.pdf. Accessed 1 Nov 2018.

29. European Centre for Disease Prevention and Control. Guide to public health measures to reduce the impact of influenza pandemics in Europe: "The ECDC Menu". 2009. Available at: https:/ecdc.europa.eu/sites/portal/files/ media/en/publications/Publications/0906_TER_Public_Health_Measures_for_ Influenza_Pandemics.pdf. Accessed 22 Oct 2018.

30. Ferguson NM, Cummings DAT, Fraser C, Cajka JC, Cooley PC, Burke DS. Strategies for mitigating an influenza pandemic. Nature. 2006;442(7101): 448-52.

31. Bell DM. Public health interventions and SARS spread, 2003. Emerg Infect Dis. 2004;10(11):1900-6.

32. Wilder-Smith A. The severe acute respiratory syndrome: impact on travel and tourism. Travel Med Infect Dis. 2006;4(2):53-60

33. Lo A, Cheung C, Law R. The survival of hotels during disaster: a case study of Hong Kong in 2003. Asia Pac J Tourism Res. 2006;11(1):65-80

34. World Health Organization. Pandemic Influenza Risk Management: WHO Interim Guidance. Geneva: World Health Organization; 2013. Available at: http://www.who.int/influenza/preparedness/pandemic/GIP_ PandemicInfluenzaRiskManagementInterimGuidance_Jun2013.pdf. Accessed 14 June 2018

35. Secretary of Health, Welfare and Food. Chronology of major events of the SARS incident in Hong Kong Available at: http://www.legco.gov.hk/yr03-04/ chinese/sc/sc_sars/reports/tbl/e3b-13.pdf. Accessed 19 Oct 2018.

36. Legislative Council Panel on Health Services. Legislative Council Panel on Health Services. 2009. Available at: http://www.legco.gov.hk/yr08-09/english/ panels/hs/papers/hs0511cb2-1505-1-e.pdf. Accessed 19 Oct 2018.

Ready to submit your research? Choose BMC and benefit from:

- fast, convenient online submission

- thorough peer review by experienced researchers in your field

- rapid publication on acceptance

- support for research data, including large and complex data types

- gold Open Access which fosters wider collaboration and increased citations

- maximum visibility for your research: over $100 \mathrm{M}$ website views per year

At BMC, research is always in progress.

Learn more biomedcentral.com/submissions 